Vol. 3, No. 1, 2021

https://doi.org/10.23939/jtbp2021.01.128

Volodymyr Labay ${ }^{1}$, Vitaliy Yaroslav $^{1}$, Mykola Gensetskyi ${ }^{2}$

\title{
INVESTIGATION THE EXERGETIC EFFICIENCY OF REFRIGERANT R290 (PROPANE) APPLICATION FOR WORK OF AIR SPLIT-CONDITIONER
}

\author{
Lviv Polytechnic National University, \\ ${ }^{1}$ Department Heat and Gas Supply and Ventilation, \\ ${ }^{2}$ Lviv Technical and Economic College Lviv Polytechnic National University \\ wlabay@i.ua
}

(C) Labay V., Yaroslav V. and Gensetskyi M., 2021

In air split-conditioners, the degree of their energy perfection must be determined based on the analysis of their exergy efficiency. In this article the innovative mathematical model developed by the authors for exergetic analysis of the work of air split-conditioners.

For example, exergetic analysis was performed on this model for the air split-conditioner with the nominal cooling capacity $2500 \mathrm{~W}$ of "Mitsubishi Electric" firm under standard external temperature conditions and received the output-input exergetic ratio (OIER) and exergetic losses in the air splitconditioner individual elements on the refrigerants R410A, R32 and refrigerant R290 (propane). It is shown that the the exergetic efficiency of the air split-conditioner increased by $9.3 \%$ and $5.1 \%$, when using the $\mathbf{R} 290$ refrigerant compared to $\mathrm{R} 410 \mathrm{~A}$ and $\mathrm{R32}$, respectively.

Keywords: air split-conditioner, exergetic balance, exergetic output-input exergetic ratio (OIER), exergetic losses, refrigerant, refrigerating machine.

\section{Introduction}

In Ukraine, the resources of the main energy commodities are limited, namely oil and gas, and this makes now the problem of saving energy resources especially relevant in conditions of market economy.

Currently, the process of redistribution of the share of heat electricity consumption in the residential sector of settlements of Ukraine is underway. This has led to the constant reduction in the thermal capacity of traditional heating systems, a significant increase in tariffs for heat and gas and increased electricity consumption at home to create a comfortable indoor conditions in the warm and cold periods of the year, for which air conditioning is widely used, including air split-conditioners. In recent years, for energy-efficient operation of household refrigeration equipment, R290 refrigerant is widely used compared to other refrigerants. But this refrigerant at the same time did not find its application in air split-conditioners.

It should be noted that in order to save energy, fundamental research has been conducted in recent decades both abroad and in Ukraine from the standpoint of exergy methodology in a number of industries and technologies (Szargut, 1968; Sokolov, 1981; Silvio, 2013; Sazhin, 2000; Bejan, 1988; Bejan, 1996; Morozuk, 2006; Morozyuk, 2006; Morosuk, 2014; Tsatsaronis, 2002; Labay, 2008; Labay, 2018; Labay, 2020; Labay, 2021).

It is known that energy and exergy flows coexist. When it comes to flows of mechanical or electrical energy, they can be equal to each other, and the heat fluxes vary greatly. Exergy allows you to assess the quality of energy, not just to quantify the energy of any kind. It determines the suitability of energy in any conditions for its technical use, namely its convertibility. 
Since exergy allows you to objectively assess the energy resources of any kind, it is the only indicator of efficiency, consequently the suitability of energy resources for use. Therefore, exergy is a universal indicator of the suitability of energy resources. The possibility of increasing the OIER process is indicated by the exergy balance, on the basis of which the amount of energy resources is determined.

In the United States and some leading European countries, exergetic analysis was introduced as a mandatory section in the development of production modernization projects and plans.

So, we conducted analytical research on the developed mathematical model of operation of the air split-conditioner by exergetic method for one of the air conditioners of the company "Mitsubishi Electric" to convince of the energy efficiency of R290 refrigerant in air split-conditioners. Similar results can be obtained for any other air conditioner, any other company and with any other refrigerant. Therefore, such studies indicate their relevance.

\section{Analysis of literature data and problem decision}

In the works of R. K. Clausius, J. Szargut, R. Petela, G. Gouy, John V. Gibbs, A. Stodola, and V. M. Brodyansky, the technical and economic optimization of various technical systems, in particular refrigerating machines of air split-conditioners, successfully used for this exergetic method of analysis (Szargut, 1968; Sokolov, 1981; Silvio, 2013; Sazhin, 2000; Bejan, 1988; Bejan, 1996; Morozuk, 2006; Morozyuk, 2006; Morosuk, 2014; Tsatsaronis, 2002) . Cost estimation in energy equipment, that using energy, cannot be the only measure of its efficiency today. Fluctuations of prices do not affect exergy.

Creating a suitable microclimate in small rooms with the help of modern air split-conditioners, which have achieved a certain some technical improvement, is not promising now. It is known, that the energy efficiency of refrigerating machines of these air split-conditioners depends on the parameters of both external and internal temperature conditions of their operation and the type of refrigerant (Sokolov, 1981). Therefore, it is necessary to conduct a detailed analysis of the work of air split-conditioners refrigeration machines using various refrigerants, including R290, to further improve the efficiency of these air split-conditioners.

For this purpose, based on the work (Sokolov, 1981), the innovative mathematical model of exergy analysis of the operation of refrigerating machines of air split-conditioners has been developed by the authors, adapted for different refrigerants and manufacturers. This mathematical model makes it possible to carry out exergy investigations of the refrigerating machine as a whole one and of its individual parts, for obtaining full information about the processes of energy transformation that have place in such systems (Labay, 2008; Labay, 2018; Labay, 2020; Labay, 2021). In order to optimize the operation of the air splitconditioner refrigeration machine, we obtained the results of finding and analyzing the exergy OIR process as a whole and exergy losses in individual elements of the air split-conditioner.

So, based on analysis of available literature data, decreasing the energy costs that used by air splitconditioners can be the most complete achieved on the basis of exergy analysis, which takes into account not only the quantity but also the quality of spent energy (Labay, 2008; Labay, 2018; Labay, 2020; Labay, 2021).

\section{Purpose and tasks of the investigation}

To determine exergy OIER and exergy losses in individual elements of air split-conditioner of "Mitsubishi Electric" firm on two-component refrigerant agent R410A, one-component R32 and proposed by the authors refrigerant R290 (propane) for using in air split-conditioners, is the purpose of this work.

The following main tasks were formulated to achieve this goal:

- on R410A, R32 and R290 refrigerants under standard external temperature conditions to install exergy OIER on the example of air split-conditioner with a nominal cooling capacity of $2500 \mathrm{~W}$ from the company "Mitsubishi Electric"; 
- on R410A, R32 and R290 refrigerants to install the exergy losses in individual elements of air split-conditioner, for example, of the company "Mitsubishi Electric" with a nominal cooling capacity of $2500 \mathrm{~W}$.

\section{Methods, materials and results of researches}

The object of study in this work is a refrigeration machine with one-stage steam compressor (without the compressor effective cooling), which is used for air split-conditioners, its scheme is shown in Fig. 1, a, and on which split-conditioners refrigerating machines thermodynamic processes for air cooling are investigated (Fig. 1, b).
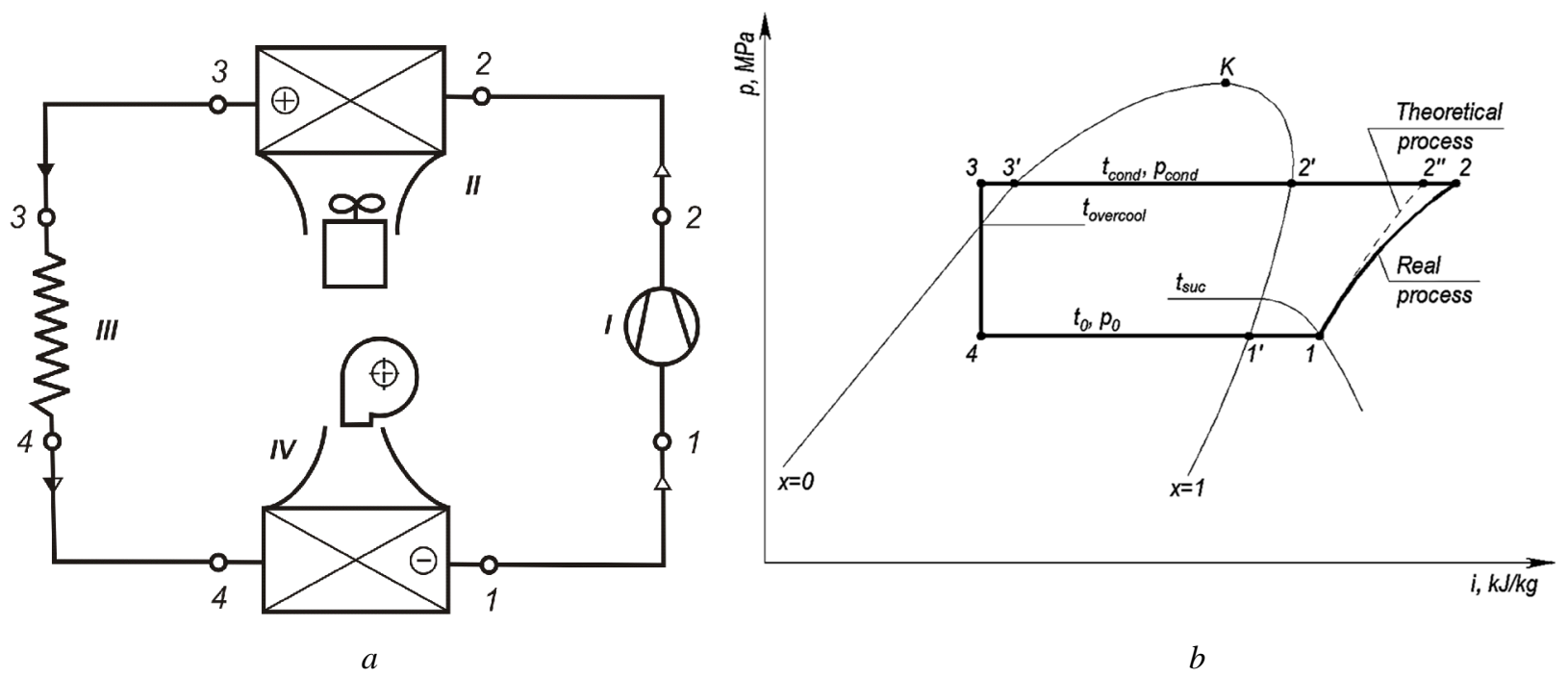

Fig. 1. Air split-conditioner refrigerating machine scheme (a) and the processes of work construction on $(p, i)$-diagram (b): 1, 2, 3, 4 are the thermodynamic cycle characteristic points;

I is compressor; II is condenser; III is capillary tube; IV is evaporator

This refrigerating machine work is as follows. In the evaporator $I V$ heat from the internal (recirculated) air of the room enters to the working refrigerating agent (RA). The working refrigerant boils in the evaporator $I V$ at the constant evaporation pressure $p_{0}=p_{e v}$ as a result of heat supplying and the evaporation temperature $t_{0}=t_{e v}$, and also overheats under pressure $p_{e v}$ from temperature $t_{e v}$ to suction temperature $t_{\text {suc }}$. After that, the compressor $I$ superheated steam is sucked out of the evaporator $I V$.

The overheated steam of the working refrigerant is compressed from the evaporation pressure $p_{e v}$ to the condensation pressure $p_{\text {cond }}$ in compressor $I$ as the temperature rises from $t_{\text {suc }}$ to $t_{2}$.

The actual compression process $1-2$ in a compressor $I$ due to friction, irreversible heat transfer and non-adiabatic does not coincide with isentropic compression 1-2".

Superheated steam enters from compressor $I$ to the condenser $I I$, where because of heat transfer to outside air (environment), there is a cooling process of the working refrigerant from the temperature $t_{2}$ to the condensation temperature $t_{\text {cond }}$ condensation process of the RA steam along the constant condensation pressure $p_{\text {cond }}$ and the condensation temperature $t_{\text {cond }}$ and process of overcooling of liquid RA under pressure $p_{\text {cond }}$ from temperature $t_{\text {cond }}$ to overcooling temperature $t_{\text {overcool }}$.

Next, after the condenser II, the liquid refrigerant is throttled through the capillary tube (throttler) $I I I$, where the throttling of the working refrigerant, the pressure falls from $p_{c o n d}$ to $p_{e v}$ and 
the temperature decreases from $t_{\text {cond }}$ to $t_{e v}$. During this the working RA partially evaporates $(\sim 20 \%)$. Finally, the working RA after the capillary tube $I I I$ enters the evaporator $I V$ and the refrigeration cycle is repeated again.

For such refrigerating machines technical characteristics, as usual, been pointed at a standard external temperature mode, which is determined by: standard temperature of surrounding environment (outside air) $t_{H 1}=35^{\circ} \mathrm{C}$ (at relative humidity $\varphi_{H 1}=40 \%$ (accordingly, moisture content $d_{H 1}=13,8 \mathrm{~g} / \mathrm{kg}$ and specific enthalpy $I_{H 1}=70.6 \mathrm{~kJ} / \mathrm{kg}$ )) (here the index $H$ is heat) and standard temperature of the conditioned internal (recirculation) air in a room $t_{C 1}=27^{\circ} \mathrm{C}$, according to temperature of surrounding environment (at relative humidity $\varphi_{C 1}=46 \%$ ) (accordingly, moisture content $d_{C 1}=10.1 \mathrm{~g} / \mathrm{kg}$ and specific enthalpy $I_{C 1}=52.8 \mathrm{~kJ} / \mathrm{kg}$ )) (here the index $\mathrm{C}$ is cool).

To calculate the standard cooling process shown in $(p, i)$ - diagram of the stationary thermal state of refrigeration machine, when in the unit time through each of its element (compressor, condenser, capillary tube and evaporator) a constant amount of the refrigerant circulates. The values given for calculation are: cooling capacity $Q_{C}, \mathrm{~W}$, consumable power $N_{\text {in }}, \mathrm{W}$, amount of condensate on the evaporator $W_{\text {cond }}, 1 / \mathrm{h}$, and during operation of one-component RA in the refrigerating machine of air split-conditioner its internal temperature mode is defined by four temperatures $t_{e v}, t_{s u c}, t_{\text {cond }}, t_{\text {overcool }}$, which are determined by external temperature mode and air flows on the evaporator $L_{e v}, \mathrm{~m}^{3} / \mathrm{h}$, and the condenser $L_{c o n d}, \mathrm{~m}^{3} / \mathrm{h}$.

The processes of operation of the refrigeration machine of the air split-conditioner is based on $(p, i)-$ diagram and is shown in Fig. $1, b$.

Note the processes that characterize the cut-offs that are obtained on the (p,i)-diagram (Fig. 1, $b$ ).

$1-2$ " is theoretical (adiabatic $s_{1}=$ const) compression in the compressor of dry overheated steam of the RA from the evaporation pressure $p_{e v}$ to the condensation pressure $p_{c o n d}$.

1-2 is real (polytropic) compression in the compressor of dry overheated steam of the RA from the evaporation pressure $p_{e v}$ to the condensation pressure $p_{\text {cond }}$.

$2-2^{\prime}$ is isobaric cooling ( $p_{\text {cond }}=$ const) of overheated steam of the RA in the condenser from the temperature $t_{2}$ to the temperature of condensation (saturation) $t_{c o n d}$ due to removal of heat by cooling external air (environment).

$2^{\prime}-3^{\prime}$ is isobaric-isothermal $\left(p_{\text {cond }}=\right.$ const, $t_{\text {cond }}=$ const $)$ condensation of steam of the RA in the condenser due to removal of heat by cooling external air.

$3^{\prime}-3$ is isobaric overcooling $\left(p_{\text {cond }}=\right.$ const) of the liquid refrigerant in the condenser from the condensation temperature $t_{\text {cond }}$ to the overcooling temperature $t_{\text {overcool }}$ due to removal of heat by cooling external air.

3-4 is isoenthalpic $\left(i_{3}=\right.$ const) throttling of the liquid refrigerant in the capillary tube with a decrease in pressure from $p_{\text {cond }}$ to $p_{e v}$.

4- 1 ' is isobaric-isothermal ( $p_{e v}=$ const, $t_{e v}=$ const) evaporation of the liquid RA in the evaporator due to the heat supply from the cooled internal (recirculation) air of the room.

$l^{\prime}-1$ is isobaric ( $p_{e v}=$ const) overheating of the RA steam in the evaporator from the evaporation temperature $t_{e v}$ to the suction temperature $t_{s u c}$ due to the heat supply from the cooled indoor air of the room.

Refrigerant supercooling (line 3'-3) compensates losses during throttling and increases cooling capacity of the air conditioner. Some overheating of the RA steam before suction in a compressor (line 1 '- 1 ) provides the "dry" compressor stroke. 
Then find the parameters of the working refrigeration agent in the characteristic points of the scheme of air conditioner refrigerating machine or by using the thermodynamic $(p, i)$ - diagram of RA or by using its tables (Jakobsen, 2001; Mitsubishi, 2021) or according to the formulas obtained by the authors on the basis of the tables for the corresponding RA and valid in the temperature range $0 \ldots 50^{\circ} \mathrm{C}$.

For calculating the exergetic OIER and analysis of work of refrigerating machine of air splitconditioner, the following output data are necessary to have:

- standard cooling capacity of air split-conditioner $Q_{C}^{s t}, \mathrm{~W}$;

- the internal air temperature at the enter $t_{C 1}=27^{\circ} \mathrm{C}$ in the evaporator and the inflow one at the exit $t_{C 2}$ from it;

- the temperature of the outside air at the enter $t_{H 1}=35^{\circ} \mathrm{C}$ and at the exit $t_{H 2}$ from the condenser;

- thermodynamic properties of RA - refrigerants R410A, R32 and R290;

- scheme of the refrigeration unit (Fig. 1,a).

Initially, for the evaporator of the air split-conditioner, which cools the indoor air of room with the initial standard temperature $t_{C 1}=27^{\circ} \mathrm{C}$, calculated the evaporation temperature and for the condenser of the air split-conditioner, which heats the outside air with the initial standard temperature $t_{H 1}=35^{\circ} \mathrm{C}$, calculated the condensation temperature and the temperature of suction of refrigerant vapor in the compressor and the supercooling of liquid refrigerant in the condenser.Then the process of work of the refrigerating machine without cooling the compressor in the thermodynamic corresponding $(p, i)-$ diagram (Fig. 1, $b$ ) has been built. In the characteristic points of the scheme by the diagram or by tables or by formulas, the parameters of the refrigerant have been finding (Jakobsen, 2001; Mitsubishi, 2021).

The heat consumption per unit cost of the working refrigerant in individual units of the air splitconditioner refrigeration machine according to the thermodynamic $(p, i)$ - diagram is revealed.

The air split-conditioner specific internal indicator work of the compressor is:

$$
l_{i}=i_{2}-i_{1}, \mathrm{~kJ} / \mathrm{kg} \text {, }
$$

where $i_{1}$ and $i_{2}$ at the corresponding points of the refrigeration cycle are the specific enthalpy, $\mathrm{kJ} / \mathrm{kg}$.

Then find according to the formula the cooling ratio of the air split-conditioner installation:

$$
\varepsilon=\eta_{e m} q_{0} / l_{i}
$$

where $\eta_{e m}$ is the electromechanical OIR of the compressor $\left(\eta_{e m}=0.9\right) ; q_{0}=i_{1}-i_{4}, \mathrm{~kJ} / \mathrm{kg}$ is specific heat consumption in the evaporator per unit cost of the refrigerant.

The air split-conditioner refrigeration machine OIER have founded by the formula:

$$
\eta_{e}=E_{C} \cdot \varepsilon
$$

where $E_{C}=T_{e n v} / \bar{T}_{C}-1$ is electric energy (exergy) specific consumption in the ideal cycle, which is attributed to the unit of heat, was fed to the heat sink (evaporator) with the average temperature $\bar{T}_{C}, \mathrm{~K}$; $T_{e n v}$ is ambient temperature, $\mathrm{K}$.

The value of exergy of the refrigerant in the characteristic points of the process have determined by the formula:

$$
e=i-i_{e n v}-T_{e n v}\left(s-s_{e n v}\right), \mathrm{kJ} / \mathrm{kg},
$$

where $i$ is the value of the specific enthalpy of the refrigerant in the characteristic points of the process, $\mathrm{kJ} / \mathrm{kg} ; i_{e n v}$ is the value of the specific enthalpy of the refrigerant in the state $T_{e n v}, p_{e n v}$ (temperature and pressure of the environment), which is in equilibrium with the environment, $\mathrm{kJ} / \mathrm{kg} ; s$ and $s_{e n v}$ are corresponding values of the refrigerant entropy, $\mathrm{kJ} /(\mathrm{kg} \cdot \mathrm{K})$, which have been determined by thermodynamic tables or diagrams or formulas (Jakobsen, 2001; Mitsubishi, 2021).

Then find in the form of electric energy, which is introduced into the air split-conditioner refrigeration machine, the specific amount of exergy supplied directly to the electric motor of the compressor, according to the formula:

$$
e_{\text {in }}=N_{\text {in }} \cdot 10^{-3} / G, \mathrm{~kJ} / \mathrm{kg},
$$

where $N_{\text {in }}$ is the power consumed by the compressor electric motor, W; $G=Q_{C} \cdot 10^{-3} / q_{0}$ is in the contour of refrigerating machine quantity of circulating refrigeration agent, $\mathrm{kg} / \mathrm{s}$. 
The refrigerating machine of the air split-conditioner losses of exergy in some apparatus is:

$$
d=e_{\text {beg }}-e_{\text {end }}, \mathrm{kJ} / \mathrm{kg} \text {, }
$$

or as a percentage of the entered into the refrigerating machine exergy:

$$
D=\left(e_{\text {beg }}-e_{\text {end }}\right) \cdot 100 / e_{\text {in }}, \%,
$$

where $e_{b e g}$ and $e_{\text {end }}$ are value of the specific exergy of the refrigerant in the beginning and at the end of the process in the air split-conditioner refrigeration machine separate apparatus, $\mathrm{kJ} / \mathrm{kg}$.

The exegetic balance of the one-stage steam-compressor refrigerating machine (without effective cooling of compressor) of the air split-conditioner for $1 \mathrm{~kg} / \mathrm{s}$ of the flow of a circulating working refrigerant has the form (Labay, 2008; Labay, 2018; Labay, 2020; Labay, 2021):

$$
e_{\text {in }}=e_{\text {out }}+\Sigma d, \mathrm{~kJ} / \mathrm{kg} \text {, }
$$

or as a percentage of $e_{i n}$

$$
E_{\text {in }}=E_{\text {out }}+\Sigma D, \%
$$

where $e_{i n}$ is the quantity of the specific exergy, that enters into refrigerating machine of conditioner, $\mathrm{kJ} / \mathrm{kg} ; e_{\text {out }}$ is the quantity of the specific exergy, which comes out from the refrigerating machine of the conditioner, $\mathrm{kJ} / \mathrm{kg} ; \Sigma d$ are total losses of specific exergy in all apparatuses of the refrigerating machine of the conditioner, $\mathrm{kJ} / \mathrm{kg} ; E_{\text {in }}, E_{\text {out }}, \Sigma D$ are respectively, exergy of the refrigerating machine of air splitconditioner, which is spent on maintaining the process of its work; the increase of exergy of air in airconditioned premises; total losses of exergy in all apparatuses of the refrigerating machine of the air conditioner as a percentage ( $\%$ ) of the exergy $e_{i n}$, which is included in the refrigerating machine.

Losses of exergy in the refrigerating machine of the air conditioner consists of losses of exergy in the compressor, the condenser, the capillary tube (throttle) and the losses of exergy due to the irreversible heat transfer in the evaporator, i.e.

$$
\begin{gathered}
\Sigma d=d_{\text {compr }}+d_{\text {cond }}+d_{t h r}+d_{e v}^{\text {irrev.h.tr }}, \mathrm{kJ} / \mathrm{kg} \\
\Sigma D=D_{\text {compr }}+D_{\text {cond }}+D_{t h r}+D_{e v}^{\text {irrev.h.tr }}, \%
\end{gathered}
$$

where $D_{\text {compr }}, D_{\text {cond }}, D_{t h r}, D_{e v}^{\text {irrev.h.tr }}$ are respectively, losses of exergy in the compressor, the condenser, the capillary tube and the evaporator, $\%$.

The exergetic balance of this refrigerating machine of the air split-conditioner based on its principal scheme (Fig. 1,a).

Obviously, the perfection of the refrigerating machine of the air split-conditioner and its elements is that higher, the higher the exergetic OIR is, which was also determined from the exergetic balance, namely (Szargut, 1968; Sokolov, 1981; Labay, 2008; Labay, 2018; Labay, 2020; Labay, 2021):

$$
\eta_{e}=E_{\text {out }} / E_{\text {in }} \text {. }
$$

Calculation the refrigerating machine of air split-conditioner the exergetic OIR creates conditions for solving the issue of saving fuel and energy resources (Szargut, 1968; Sokolov, 1981; Labay, 2008; Labay, 2008; Labay, 2010; Labay, 2018).

Consequently, the exergetic OIER of the refrigerating machine of air split-conditioner also have been calculated by the formula (12), in which the numerator is a useful exergetic effect, and the denominator is the cost of exergy.

We have calculated the OIER of the air split-conditioner refrigeration machine with one-stage steam compressor of "Mitsubishi Electric" firm with nominal cooling capacity $Q_{C}^{s t}=2500 \mathrm{~W}$ at standard temperature conditions on refrigerants R410A, R32 and R290. For the calculation were accepted:

- overcooling of the liquid refrigerant in the condenser $\Delta t_{\text {overcool }}=5{ }^{\circ} \mathrm{C}$;

- overheating of the refrigerant vapor in the evaporator $\Delta t_{\text {overheat }}=10^{\circ} \mathrm{C}$; 
- final temperature difference in the evaporator (internal air and boiled refrigeration agent) $\Delta t_{e v}=2.8{ }^{\circ} \mathrm{C}$;

- final temperature difference in the condenser (external air and condensing refrigerant) $\Delta t_{\text {cond }}=4.2{ }^{\circ} \mathrm{C}$.

For calculations on the computer mathematical model the $(p, i)$ - diagram of the refrigerants $\mathrm{R} 410 \mathrm{~A}, \mathrm{R} 32$ and $\mathrm{R} 290$ in the temperature range $0 \ldots 50^{\circ} \mathrm{C}$ was fed as analytical dependences $p=f(t)$, $i=\varphi(t), s=\psi(t)$.

The calculation results are summarized in Table 1.

Table 1

\section{Results of calculating of OIER and exergetic losses in the air split-conditioner elements} with nominal cooling capacity $2500 \mathrm{~W}$ of "Mitsubishi Electric" firm

\begin{tabular}{|c|c|c|c|c|c|}
\hline \multirow{2}{*}{$\begin{array}{c}\text { Refrigeration } \\
\text { agent }\end{array}$} & \multicolumn{2}{|c|}{ Exergetic losses in the air split-conditioner elements, \% } & \multicolumn{2}{c|}{$\begin{array}{c}\text { Exergetic OIR } \\
n_{e}, \%\end{array}$} \\
\cline { 2 - 5 } & $D_{\text {compr }}$ & $D_{\text {cond }}$ & $D_{\text {thr }}$ & $D_{e v}^{\text {irrev.h.tr }}$ & 22.6 \\
\hline R410A & 26.9 & 21.3 & 10.5 & 18.7 & 23.5 \\
\hline R32 & 27.1 & 22.4 & 4.8 & 22.2 & 24.7 \\
\hline R290 & 27.0 & 20.7 & 7.5 & 20.1 & \\
\hline
\end{tabular}

The growth of the OIER due to transition from the refrigerants R410A and R32, respectively, to the proposed by the authors for use in split-conditioners refrigerant $\mathrm{R} 290$, is:

$$
\Delta_{\mathrm{R} 290}=\frac{24.7-22.6}{22.6} \cdot 100=9.3 \% ; \quad \Delta_{\mathrm{R} 290}=\frac{24.7-23.5}{23.5} \cdot 100=5.1 \% .
$$

The Grassmann's diagram of the exergetic flows of the air split-conditioner refrigeration machine, according to the results of calculation, have been built (Fig. 2).

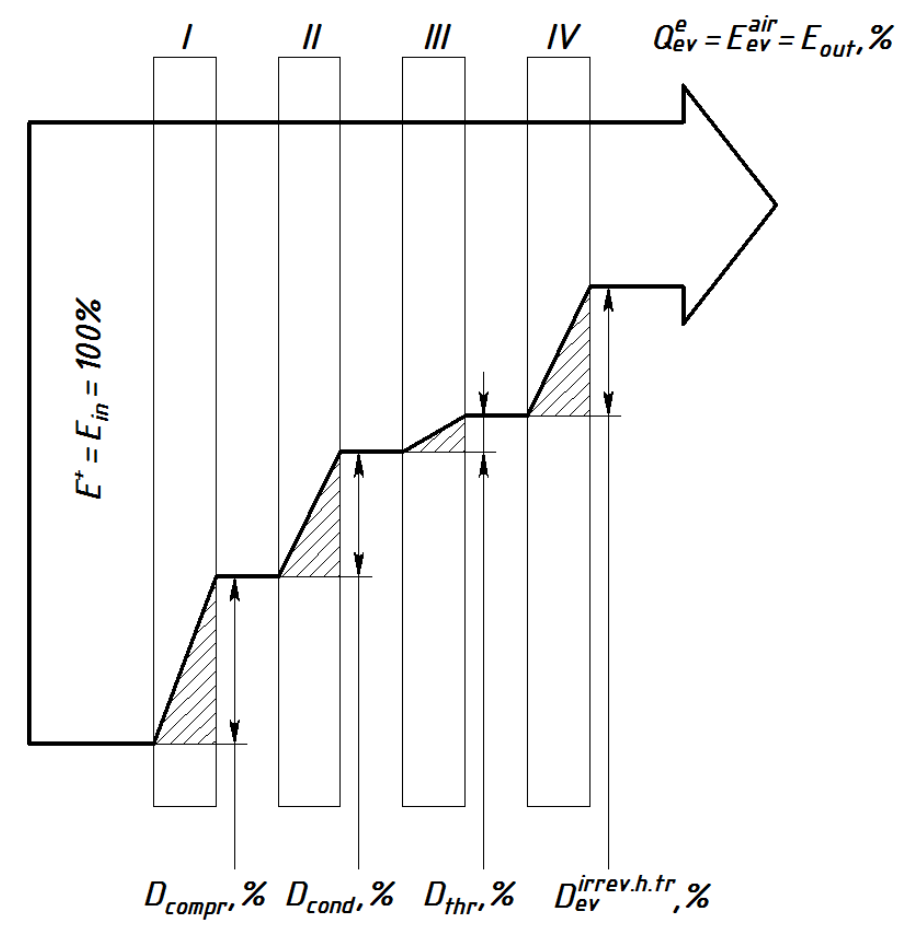

Fig. 2. The exergetic flows of the air split-conditioner refrigeration machine in the Grassmann's diagram:

$D_{\text {compr }}, D_{\text {cond }}, D_{\text {thr }}, D_{e v}^{\text {irrev.h.tr }}$ are respectively, exergetic losses in the compressor, the condenser, the capillary tube and the evaporator, \% 


\section{Conclusions}

R290 refrigerant is widely used in household refrigeration equipment, which has led to its more energy-efficient operation compared to other refrigerants. At the same time, this refrigerant has not been used in air split-conditioners.

This allowed substantiating the relevance of the research task, which is due to insufficient information on the effectiveness of the use of various refrigerants in air split-conditioners. The author's innovative mathematical model for the analysis of work of one-stage freon refrigerating machines used in split-conditioners, by an exergetic method is developed. This model obtained exergetic efficiency and losses of exergy in individual elements of the air split-conditioner on the example of an air conditioner with a nominal cooling capacity of $2500 \mathrm{~W}$ from „Mitsubishi Electric” firm at standard outdoor temperature conditions on refrigerants R410A, R32 and proposed by the authors for use in air splitconditioners refrigerant R290 (propane). R290 refrigerant has been found to be the most effective in terms of exergetic efficiency.

The use of R290 refrigerant compared to R410A and R32 showed an increase in the exergetic efficiency of the split air conditioner by $9.3 \%$ and $5.1 \%$, respectively. The exergy losses found in all elements of the air split-conditioner refrigeration indicate the need to improve the air split-conditioner equipment in order to reduce the exergy losses in them and to increase its exergy efficiency in general.

The mathematical model of the split-conditioner operation can be applied to different air splitconditioner models, to different types of refrigerants, provided the thermodynamic properties of the refrigerant and the characteristics of the split-conditioner are known.

\section{References}

Szargut J., Petela R. (1968). Exergy. Moscow: Energy (in Russian).

Sokolov E. Ya., Brodiansky V. M. (1981). Energy bases of heat transformation and cooling processes. Moscow: Energoizdat (in Russian).

Silvio de Oliveira Junior. (2013). Exergy. Production, Cost and Renewability. Springer (in English).

Sazhin B. S., Bulekov A. P., Sazhin B. S. (2000). Exergy Analysis of Work of Industrial. Moscow: Moskovskij gos. tekstil'nyj un-t, (in Russian).

Bejan A. (1988) Advanced Engineering Thermodynamics. New York: J. Wiley (in English). English).

Bejan A., Tsatsaronis G., Moran M. (1996). Thermal Design and Optimization. New York: J. Wiley (in

Morosuk T., Nikulshin R., Morosuk L. (2006). Entropy-Cycle Method for Analysis of Refrigeration Machine and Heat Pump Cycles. THERMAL SCIENCE 10 (1), 111-124 (in English).

Morozyuk T. V. (2006). The theory of refrigeration machines and heat pumps. Odessa: Studio "Negotsiant" (in Russian).

Morosuk T. V. (2014). New step in the development of exergy analysis. Refrigeration Engineering and Technology 4 (150), 13-17. (in English). https://doi.org/10.15673/0453-8307.4/2014.28045.

Tsatsaronis J., Morozyuk T. (2002) The interaction of thermodynamics and economics to minimize the cost of an energy conversion system. Odessa: Studio "Negotsiant" (in Russian).

Labay V. Yo., Khanyk Ya. M. (2008). Used in Air Split-conditioners Refrigerants R407C and R410A. Refrigeration Engineering and Technology 3 (113), 13-17 (in Ukrainian).

Labay V., Dovbush O., Yaroslav V. and Klymenko H (2018). Mathematical Modeling of a Split-conditioner Operation for Evaluation of Exergy Efficiency of the R600A Refrigerant Application. Scientific Journal "Mathematical Modeling and Computing" 5 (2), 169-177 (in English). https://doi.org/10.29939/mmc2018.02.169.

Labay V. Yo., Yaroslav V. Yu., Dovbush O. M. and Tsizda A. Ye. (2020). Mathematical Modeling of an Air Split-Conditioner Heat Pump Operation for Investigation its Exergetic Efficiency Scientific Journal "Mathematical Modeling and Computing" 7 (1), 169-178 (in English). https://doi.org/10.23939/mmc2020.01.169.

Labay V., Yaroslav V., Dovbush O. and Piznak B. (2021). Dependence of Evaporation Temperature and Exergetic Efficiency of Air Split-Conditioners Heat Pumps from the External Air Temperature. In: Blikharskyy Z. (eds) Proceedings of EcoComfort 2020. EcoComfort 2020. Lecture Notes in Civil Engineering, 100, $253-259$. Springer, Cham (in English). https://doi.org/10.1007/978-3-030-57340-9_31. 
Jakobsen A., Rassmussen B.-D., Skovrup M.-J., Andersen S.-E. (2001). CoolPack - a collection of simulation tools for refrigeration - Tutorial - Version 1.46. - Department of Energy Engineering Technical University of Denmark (in English).

Mitsubishi Electric Catalogo Split (2021). (in English).

В. Й. Лабай ${ }^{1}$, В. Ю. Ярослав ${ }^{1}$, М. П. Генсецький ${ }^{2}$ Національний університет “Львівська політехніка", ${ }^{1}$ кафедра теплогазопостачання і вентиляції,

2 Львівський техніко-економічний коледж

\title{
ДОСЛІДЖЕННЯ ЕКСЕРГЕТИЧНОЇ ЕФЕКТИВНОСТІ ЗАСТОСУВАННЯ ХОЛОДОАГЕНТУ R290 (ПРОПАНУ) ДЛЯ РОБОТИ СПЛІТ-КОНДИЦІОНЕРА
}

\author{
(С Лабай В. Й., Ярослав В. Ю., Генсещький М. П., 2021
}

Останнім часом за кордоном та в Україні для заощадження енергетичних ресурсів ведуться фундаментальні дослідження низки технологій із позицій ексергетичної методології. Тому в splitкондиціонерах ступінь їх енергетичної досконалості потрібно визначати на основі аналізу їх ексергетичної ефективності.

У побутовій холодильній техніці широко застосовується холодоагент R290, що сприяла іiі енергоощаднішій експлуатації порівняно з іншими холодоагентами. У той самий час у split-кондиціонерах цей холодильний агент не застосовують.

Це дало змогу обгрунтувати актуальність дослідницького завдання, що пов'язано 3 недостатньою інформацією щодо ефективності використання різних холодоагентів у split-кондиціонерах. Для аналізу роботи одноступеневих фреонових холодильних машин, які використовують у splitкондиціонерах, розроблено авторську інноваційну математичну за ексергетичним методом. На цій моделі отримано ексергетичний коефіцієнт корисної дії (ККД) та втрати ексергії в окремих елементах split-кондиціонера на прикладі кондиціонера 3 номінальною холодопродуктивністю 2500 Вт фірми "Mitsubishi Electric" за стандартних зовнішніх температурних умов на холодоагентах R410A, R32 i холодоагенту R290 (пропану) який запропонували автори для використання у split-кондиціонерах. Виявлено, що за ексергетичним ККД холодильний агент R290 є найефективнішим. Використання холодоагенту R290 порівняно з R410A i R32 збільшила ексергетичну ефективність split-кондиціонера на 9,3\% і 5,1 \%, відповідно. Втрати ексергії, встановлені в усіх елементах холодильної машини splitкондиціонера, вказують на необхідність удосконалення обладнання split-кондиціонера, щоб зменшити втрати ексергії в них та загалом збільшити його ексергетичний ККД.

Ключові слова: split-кондиціонер, ексергетичний баланс, ексергетичний ККД, ексергетичні втрати, холодоагент, холодильна машина. 